\title{
Photodynamic Effect on Photosensitized Candida albicans with Hematoporphyrin Derivative Using Low Power Diode Laser In Vitro
}

\author{
Ahmed S. Al-Khafaji \\ Department of Biology \\ College of Science \\ University of Baghdad
}

(Received 20/7/2010 ; Accepted 26/9/2011)

\begin{abstract}
In this study, the Photodynamic Effect (PDE) of Hematoporphyrin derivative (HpD) combined with irradiation from low power laser on Candida albicans was investigated. Four isolates of $C$. albicans were diagnosed in seven samples collected from oral cavity of adults with dental caries. Laser irradiation used in this study has been emitting from Diode laser at a wavelength equal to $630 \mathrm{~nm}$ (red region of the spectrum), while the output power was approximately $10 \mathrm{~mW}$ as a continuous wave. The exposure time of irradiation was between (30-240) seconds, irradiation area was $(0.125) \mathrm{cm}^{2}$. C. albicans were exposed to irradiation after its exposure to several concentrations of $\mathrm{HpD}$ these concentrations were varied from (16-128) $\mu \mathrm{g} / \mathrm{ml}$. The results clearly showed the Photodynamic effect in killing C. albicans which was photosensitized by $\mathrm{HpD}$ in combination with laser irradiation. There was no determined effect on yeast cells viability neither by the using $\mathrm{HpD}$ concentrations nor irradiation doses separately. It could be concluded that PDE of $\mathrm{HpD}$ by low power laser irradiation at wavelength $630 \mathrm{~nm}$ on Candida albicans was a powerful technique in growth inhibition of that pathogenic yeast In vitro.
\end{abstract}

Keywords: photodynamic effects, Candida albicans, hematoporphyrin, diode laser.

\section{التأثير الحركي الضوئي عل خميرة Candida albicans المهسة ضومئيا بمشنق الهيماتوبورفرين بلستهمل ليزر الثنائي ني القرة الولائة خارج الجمم}

\section{الملغص}

مم التحري في هذه الدرلسة عن التأثير الحركمي الضوئي لمشق الهيماتوبورورين (HpD) بالاقتران مع

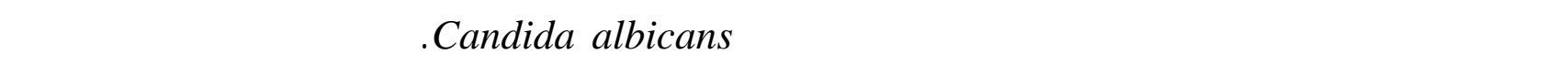
C. albicans الليزر المستخم في هذه الدرلسة ينبعث من ليزر الثنائي ططولموجي 630 نانومتر(مطقة الطف الحمراء)، 
لما الخرج الليزري فكان 10 ملي وطا تقريبا وهو ليزر مستمر الموجة. فترات التعرض للتشعبع تراوح ـت

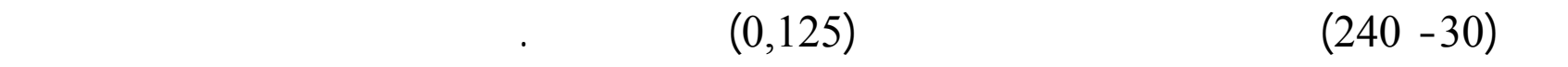

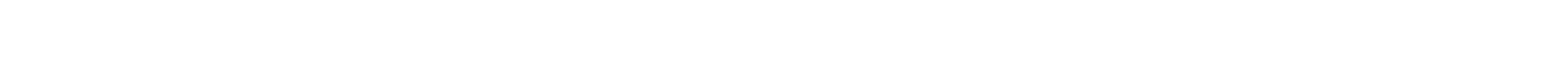

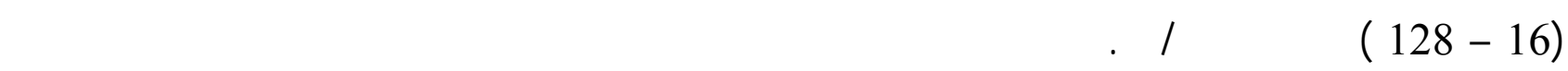

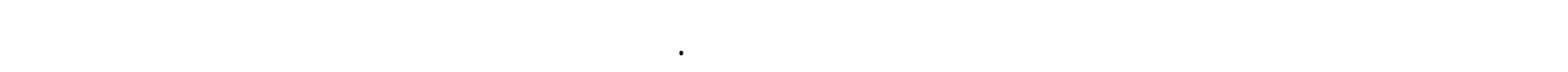

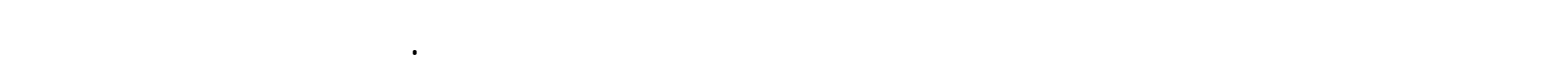

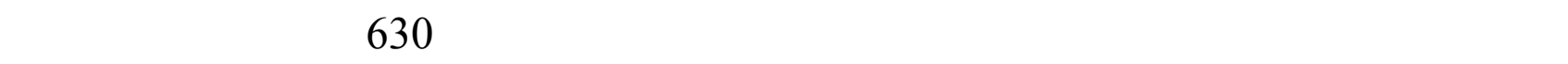

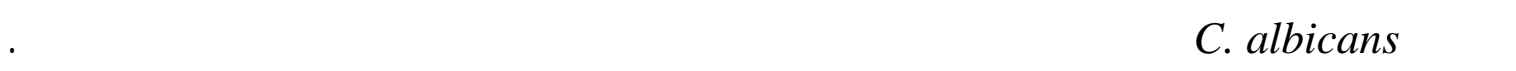
الكامل الدالة: التأثير الحركي الضوئي، خميرة الكاننيدا البيضاء، الهيماتوبورفرين، ليزر الثنائي.

\section{INTRODUCTION}

Photodynamic Effect (PDE) is providing a technique of killing microorganisms in localized and topical infections (Malik et al., 1990; Wilson, 1993). It can be defined as destruction of photosensitized cells by free radical ions such as singlet oxygen $\left({ }^{1} \mathrm{O}_{2}\right)$ produced by binary mechanism of a photosensitizing agent and irradiation of an appropriate wavelength (Dougherty et al., 1998). Despite the PDE or what is called Photodynamic Action (PDA) is widely accepted for clinical application to treat neoplastic cells, but is also accepted for antimicrobial inhibition dynamically. A large number of microorganisms (including oral species) have been reported to be killed In vitro by this technique (Paardekooper et al., 1995; Wilson et al., 1992). PDE includes delivering irradiation of the appropriate wavelength to excite the photosensitizing agent (photosensitizer) from ground or triplet state to singlet state. This excited state may then undergoing intersystem crossing to the slightly lower energy, which may then react further by two processes known as Type I and Type II photochemical reactions, both of them require molecular oxygen (Ochsner et al., 1997). The Type I photochemical reaction includes electron-transfer reactions from the triplet state of photosensitizer to produce free radical ions which can react with oxygen to produce cytotoxic species, such as singlet superoxide anions (Athar and Bickers, 1988). The Type II photochemical reaction includes transfer of energy from the triplet state of photosensitizer to ground state molecular oxygen (triplet) to produce excited-state singlet oxygen $\left({ }^{1} \mathrm{O}_{2}\right)$, which can oxidize many biological molecules, such as proteins, nucleic acids and lipids, and then lead to photocytotoxic effects (Redmond and Gamlin, 1999). The mechanism of the generation of singlet oxygen $\left({ }^{1} \mathrm{O}_{2}\right)$ formed by the exposure to Hematoporphyrin Derivative (HpD) is considered as one of the important photodynamic techniques. There is no history of PDT can be mentioned without referring to HpD. Hematoporphyrin Derivative. They are referred to as first-generation sensitizers. HpD is the most extensively studied and clinically used photosensitizer. Recently, HpD has been used as an antimicrobial photosensitizer due to its capabilities to inhibit both gram-positive, gram-negative bacteria (Merchat et al., 1996). This photosensitizer has been successfully applied as broad spectrum antimicrobial compounds. However, in the most of studies 
determinate the techniques of pathogenic yeast photodynamic inhibition, the anionic hematoporphyrin and its derivatives, are used as photosensitizers to sensitize these microorganisms such as Candida albicans (Bliss et al., 2004; Bocking et al., 2000). C. albicans may be present in different sites on the body of human due to its opportunistic behavior, sometimes invading surface tissues causing candidosis (El Azizi et al., 2004; Sen et al., 1997). The presence of C. albicans had already been determined in caries lesions, in addition to its capability to infect oral tissues. It has usually known with their ability for antimicrobial resistance (Akdeniz et al., 2002 ; Baena et al., 2005). The growing resistance against antimicrobial agents has generated a search for alternative antimicrobial treatments. Particularly, the use of topical antibiotics is under discussion since it has been suggested that such an approach induces antibiotics resistance faster than the use of antibiotics. A lack of effectiveness of some of the antibiotics used may be due to development of drug-resistant strains. To overcome the problems caused by the emergence of resistance, alternative antimicrobial approaches need to be developed. One potential alternative approach is photodynamic therapy (PDT), which could provide a means of killing microbes in localized, topical infections (Kandela et al., 2004).

\section{MATERIALS AND METHODS \\ Isolation and identification of yeast}

Saliva samples for C. albicans counts were taken from saliva sublingually, from cheek and dorsum of the tongue with sterile cotton swabs. After gently rubbing, the samples were immediately inoculated onto Sabouraud dextrose agar (Difco, USA) added with $0.1 \mathrm{mg} / \mathrm{ml}$ of Chloramphenicol (Williams and Lewis, 2000). The samples were incubated at $37^{\circ} \mathrm{C}$ for 2 days and at room temperature for 5 days. The counting of CFU/plate was carried out after the growth of characteristics yeast colonies.

\section{Inoculate preparation for the PDE}

Inocula were prepared from 4 isolates of $C$. albicans obtained with the abovementioned method. They were standardized to a final concentration of $1.5 \times 10^{6}$ cells/ml, and then colony was counted on Sabouraud medium, yeast colonies growing on Sabouraud dextrose agar plate were carefully collected by a sterile wire loop, collected colonies were inoculated individually in $5 \mathrm{ml}$ of Tryptic Soy Broth (Difco, USA) contained in test tubes, they were incubated overnight at $37^{\circ} \mathrm{C}$. After the incubation, yeast cells were harvested by centrifugation at $5000 \mathrm{rpm}$ for $10 \mathrm{~min}$ and resuspended in sterile phosphate buffer saline (PBS), the cell concentration inside the test tube was equivalent to $1.5 \times 10^{6}$ cells $/ \mathrm{ml}$, the standardization of the inoculua could be performed with a McFarland standard; the turbidity of the inocula was equal to no. 2 McFarland standard.

\section{Laser irradiations}

The source of laser used in this study was diode Laser (Ever Light Co., Taiwan - it was providing by Iraqi Centre for Cancer and Medical Genetic Research). The wavelength of light that emitted from this laser and output power were determined by using a portable power meter (Edmund Optics Inc., Portland, USA), according to the measurements, the wavelength was $630 \mathrm{~nm}$ (Mang et al., 2006), and output power was approximately 10mW as a continuous wave. The irradiation area was $(0.125) \mathrm{cm}^{2}$ while the exposure time of irradiation was (30-240) seconds (Table 1). 


\section{Preparation of photosensitizer solutions}

Photosensitizer solutions were prepared in dark chamber as stock solutions of a $1 \mathrm{mg} / \mathrm{mL}$ Hematoporphyrins derivatives (HpD) (Sigma Aldrich, Germany) in phosphate buffer and Ethanol, then shaken by vortex mixer for $3 \mathrm{~min}$ at room temperature $\left(25^{\circ} \mathrm{C}\right)$, and stored in the dark.

\section{Spectral analysis of $\mathbf{H p D}$}

Peaks of absorbance for $\mathrm{HpD}$ were detected by a Double beam spectrophotometer (Varian Cary 100UV-Vis Spectrophotometer, Australia- providing by Department of Biology/ College of Science/ University of Baghdad). UV-Visible absorption spectra of photosensitizer were determined as a plot of absorbance against wavelength $(300-750 \mathrm{~nm})$ for both stock solutions of HpD.

Photosensitization: sixteen experimental conditions had been tested, applied by crossing the four concentrations of $\operatorname{HpD}(16,32,64,128) \mu \mathrm{g} / \mathrm{ml}$ with four different exposure periods of irradiation $(30,60,120,240)$ second, by the using a modified microtiter plat (Al-Khafaji, 2002; Kandela et al., 2004). 24-wells from 96-wells plate were selected to be a matrix for crossing tests, each well was covered by irradiation area which was $(0.125) \mathrm{cm}^{2}$, aliquots of $100 \mu 1$ of the cell suspensions were photosensitized with different above concentrations of $\mathrm{HpD}$. The wells containing the resulting suspensions were left to rest in the dark (because of $\mathrm{HpD}$ is a photosensitive compound) for half hour (to allow the HpD for entering the yeast cells). This method was determined the effect of irradiation on photosensitized yeast cells $\left(\mathrm{L}^{+} \mathrm{P}^{+}\right)$. Furthermore, positive and negative controls of each irradiation effect alone $\left(\mathrm{L}^{+} \mathrm{P}^{-}\right)$ and $\mathrm{HpD}$ effect alone $\left(\mathrm{L}^{-} \mathrm{P}^{+}\right)$were respectively evaluated too. In addition, control without any treatment $\left(\mathrm{L}^{-} \mathrm{P}^{-}\right)$has been used as a reference control (Table 1). After treatments, aliquots $(100 \mu \mathrm{L})$ were plated from each well onto Sabouraud Dextrose Agar with chloramphenicol and allowed to grow for $24-48 \mathrm{~h}$ at $28-37^{\circ} \mathrm{C}$. The number of colonies were counted by direct plate enumeration and expressed as colony forming units $(\mathrm{CFU} / \mathrm{mL})$.

\section{Statistical analysis}

$t$-test was performed to investigate whether there were significant differences between the variable test conditions, and the difference was considered to be significant when $p<0.05$.

\section{RESULTS}

The morphological characteristics of C. albicans colonies were microscopically confirmed. Gram staining was utilized in order to recognize other types of cells. The colonies that presented gram-positive budding cells of yeasts were sub-cultured and identified. After incubation at $37^{\circ} \mathrm{C}$ for 2 days, the control plates $\left(\mathrm{L}^{-} \mathrm{P}^{-}\right)$of the four $C$. albicans isolates showed abundant growth of viable colonies. It was observed that the sensitizing effect of the four concentrations of $\mathrm{HpD}\left(\mathrm{L}^{-} \mathrm{P}^{+}\right)$did not significantly alter the number of $\mathrm{CFU} / \mathrm{ml}$, in comparison with the values detected in the control groups $(p>0.05)$. On the other hand, the four treatment of irradiation effect $\left(\mathrm{L}^{+} \mathrm{P}^{-}\right)$showed a little significantly higher $\mathrm{CFU} / \mathrm{mL}$ values $(p<0.05)$ at an exposure time equal to $240 \mathrm{sec}$ in comparison with those detected in the control group. For all the treatments, a significant reduction in the number of $\mathrm{CFU} / \mathrm{mL}$ was showed after photodynamic application. The effectiveness of the $\mathrm{PDE}$ in reducing cell viability had varied as a function of $C$. albicans and the association between $\mathrm{HpD}$ and the irradiation (Fig. 1). C. albicans showed no growth at $37^{\circ} \mathrm{C}$ for 2 days 
after PDT, indicating the complete inactivation of these microorganisms. Bearing in mind that certain associations of the conditions $\left(\mathrm{L}^{+} \mathrm{P}^{+}\right)$for $C$. albicans, showed no survival, it was impossible to make statistical interference. The survaival curve of photosensitized $C$. albicans showed a minimum influence by $30 \mathrm{sec}$ of laser irradiation associated with concentration $16 \mu \mathrm{g} / \mathrm{ml}$ of $\mathrm{HpD}$ photosensitizer, these were necessary to achieve a minimal inhibition of C. albicans to approximately $10 \%$. (Fig. 2). As the concentration of HpD increased and the exposure time of irradiation from the Diode laser have also increased; these were resulted in correspondingly greater killing of the C. albicans. $128 \mu \mathrm{g} / \mathrm{ml}$ concentration of $\mathrm{HpD}$ combined with exposure time $240 \mathrm{sec}$ were resulted a total growth inhibition of yeast cells. With the same exposure, more than $90 \%$ reduction in the viable counts of yeast cells sensitized with $9.6 \mu \mathrm{g} / \mathrm{ml}$ of $\mathrm{HpD}$ was showed. C. albicans had been shown more sensitivity to inhibition by photosensitization with $\mathrm{HpD}$ dissolved in ethanol than dissolved in PBS.

The results of absorption spectra showed that the absorption spectrum of $5 \mu \mathrm{g} / \mathrm{ml}$ of $\mathrm{HpD}$ in ethanol included a Soret band at $401 \mathrm{~nm}$ and Q bands at 554, and $598 \mathrm{~nm}$, while the absorption spectrum of $5 \mu \mathrm{g} / \mathrm{ml}$ of $\mathrm{HpD}$ in PBS involved a Soret band at $400 \mathrm{~nm}$ and Q bands at 550 and $591 \mathrm{~nm}$ (Table 2: $\mathrm{A}$ and $\mathrm{B}$ ). The $\mathrm{Q}$ bands of absorption spectrum were larger when ethanol was used as a solvent than when PBS was used. The value of absorption at $600 \mathrm{~nm}$ was also observed, the absorbance of HpD-ethanol sample was increased and become higher than of HpD-PBS sample (Figure 3: A and B).

\section{DISCUSSION}

This study investigated the in vitro sensitivity of Candida albicans to Photodynamic effect by combination of different concentrations of $\mathrm{HpD}$ and several doses of Diode laser irradiation. One of the most significant findings was the complete inhibitory of the viable yeast cells of $C$. albicans using low power of irradiation promoted photosensitization with optimum concentrations of $\mathrm{HpD}$. These results were considered relevant, since a few investigations observed the total elimination of C. albicans after PDE (Souza et al., 2006). Our investigations are approximately similar to those obtained for the PDE of microbial cells and other Candida species with $\mathrm{HpD}$ and the PDE of $C$. albicans with hematoporphyrin (Bertoloni et al., 1987 and Bliss et al., 2004). This study evaluated the In vitro susceptibility of $C$. albicans to PDE by means of the association of four different concentrations of $\mathrm{HpD}$ and four different energy doses of laser irradiation.

Bearing in mind that the PDE requires an association of $\mathrm{HpD}$ and light, the application of light without the presence of the $\mathrm{HpD}$ is not capable of promoting the formation of singlet oxygen. It is fundamental to have the presence of a substance to intermediate the process of reactive species formation. However, the results of condition $\mathrm{L}^{+} \mathrm{P}^{+}$showed statistically significant differences, when compared with the control groups, suggesting a possible toxic effect of Diode laser irradiation (Lambrechts et al., 2005). The photochemical processes mediated by $\mathrm{HpD}$, initially appear to promote an alteration in the cytoplasmic membranes of the microorganism. This effect possibly occurs through oxidative alterations in lipids and proteins present in those membranes (Teichert et al., 2002). Afterwards, HpD is able to penetrate into the cell and cause irreversible damage to the intracellular organelles, which leads to cellular inhibition. The increase in the permeability of the membrane during the initial photochemical processes is fundamental for accentuating the photodynamic effect 
on cell viability, as inactivation effectively occurs after the uptake of $\mathrm{HpD}$ (Al-Khafaji et al., 2010).

On other hand, C. albicans was more susceptible to PDE by HpD dissolved in ethanol, than by $\mathrm{HpD}$ dissolved in PBS. This could be due to more absorption of HpD-ethanol sample than the absorption of HpD-PBS sample at $630 \mathrm{~nm}$ (Fig. 3: A, B), where the light emission of Diode laser was closely to absorbance of Q- bands at red region of electromagnetic spectrum at $630 \mathrm{~nm}$ which has considered as effective wave length using in treatment of oral lesions (Mang et al., 2006). According results which had been shown, the potential explanation might be the Ethanol has a lower dielectric constant than water, 25.3 and 80.1 (at $293.2 \mathrm{~K}$ ), respectively (Wohlfarth, 1995). and this explains why the absorption peaks of Q-bands are better resolved in ethanol than in PBS (Figs. 3:A and 3:B), it has also been assumed that increase in absorption is due to the potential increasing of $\mathrm{HpD}$ solubility in ethanol solution (as organic solvent) comparing with PBS.

\section{CONCLUSION}

The results of present study in vitro using low power diode laser to activated photosensitive compounds to specifically target and destroy pathogenic yeast and reduce their viability may open the door widely to new approach of photo disinfection by applying this technique topically to the intended target; at that point, the treatment site was disinfected by Diode laser at $630 \mathrm{~nm}$ and energy dose settings combined with $\mathrm{HpD}$ dissolving in ethanol as a suitable solvent. These results may also serve as a parameter for future investigations, so the further studies of effectiveness of PDE on experimental animals (In vivo) extremely necessary to serve as a promising therapy of periodontitis, and if that happened will be also open the door for using against yeast infections of $C$. albicans that associate with oral cavity cancer.

Table 1: Design of photodynamic treatments.

\begin{tabular}{|c|c|c|c|c|c|c|}
\hline$(\mathrm{D}, \mathrm{C})$ & $\mathrm{T}_{0}$ & $\mathrm{~T}_{1}$ & $\mathrm{~T}_{2}$ & $\mathrm{~T}_{3}$ & $\mathrm{~T}_{4}$ & \\
\hline $\mathrm{C}_{0}$ & $\begin{array}{c}\mathrm{L}^{-}, \mathrm{P}^{-} \\
0,0\end{array}$ & 30 & 60 & 120 & 240 & $\frac{\mathrm{L}^{+} \mathrm{P}^{-}}{\text {Control }}+$ \\
\hline $\mathrm{C}_{1}$ & 0,16 & 30,16 & 60,16 & 120,16 & 240,16 & \multirow{4}{*}{$\mathrm{L}^{+} \mathrm{P}^{+}$} \\
\hline $\mathrm{C}_{2}$ & 0,32 & 30,32 & 60,32 & 120,32 & 240,32 & \\
\hline $\mathrm{C}_{3}$ & 0,64 & 30,64 & 60,64 & 120,64 & 240,64 & \\
\hline \multirow[t]{2}{*}{$\mathrm{C}_{4}$} & 0,128 & 30,128 & 60,128 & 120,128 & 240,128 & \\
\hline & $\begin{array}{l}\mathrm{L}^{-} \mathrm{P}^{+} \\
\text {Control }^{-}\end{array}$ & \multicolumn{4}{|c|}{$\overline{\mathrm{L}^{+} \mathrm{P}^{+}}$} & Test \\
\hline
\end{tabular}

$\mathrm{T}_{\mathrm{n}(0-4)}$ : The exposure time of irradiation (secon), $\mathrm{n}$ : number of treatment.

$\mathrm{C}_{\mathrm{n}(0-4)}$ : Concentration of $\mathrm{HpD}(\mu \mathrm{g} / \mathrm{ml})$, $\mathrm{n}$ : number of treatment.

$\mathrm{L}^{-} \mathrm{P}^{-}$: yeast cells without Photosesitizer $\mathrm{HpD}$ and without Laser irradiation (reference control).

$\mathrm{L}^{-} \mathrm{P}^{+}$: yeast cells Photosensitized with $\mathrm{HpD}$ and without Laser irradiation (negative control).

$\mathrm{L}^{+} \mathrm{P}^{-}$: yeast cells without Photosesitizer HpD and irradiated with Laser (positive control). 


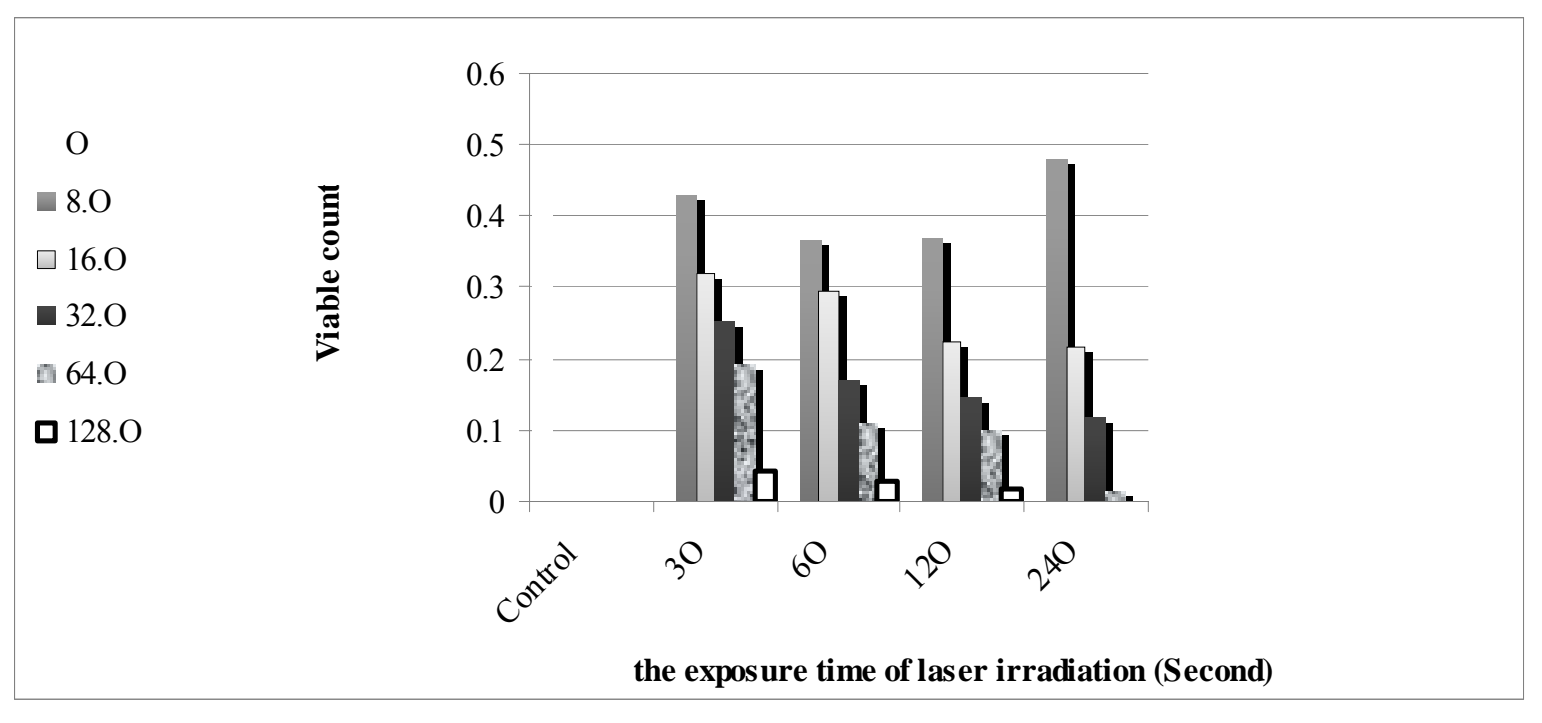

Fig. 1: Photodynamic effect on the viable count of yeast cells.
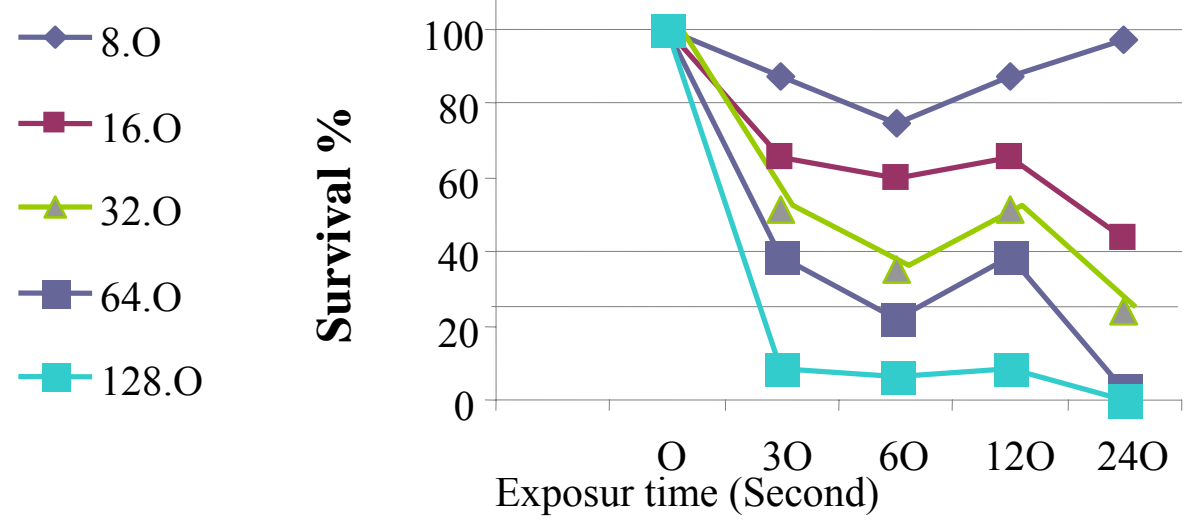

Fig.2: Survival cs of phonsitized yeast cells with HpD by diode laser 

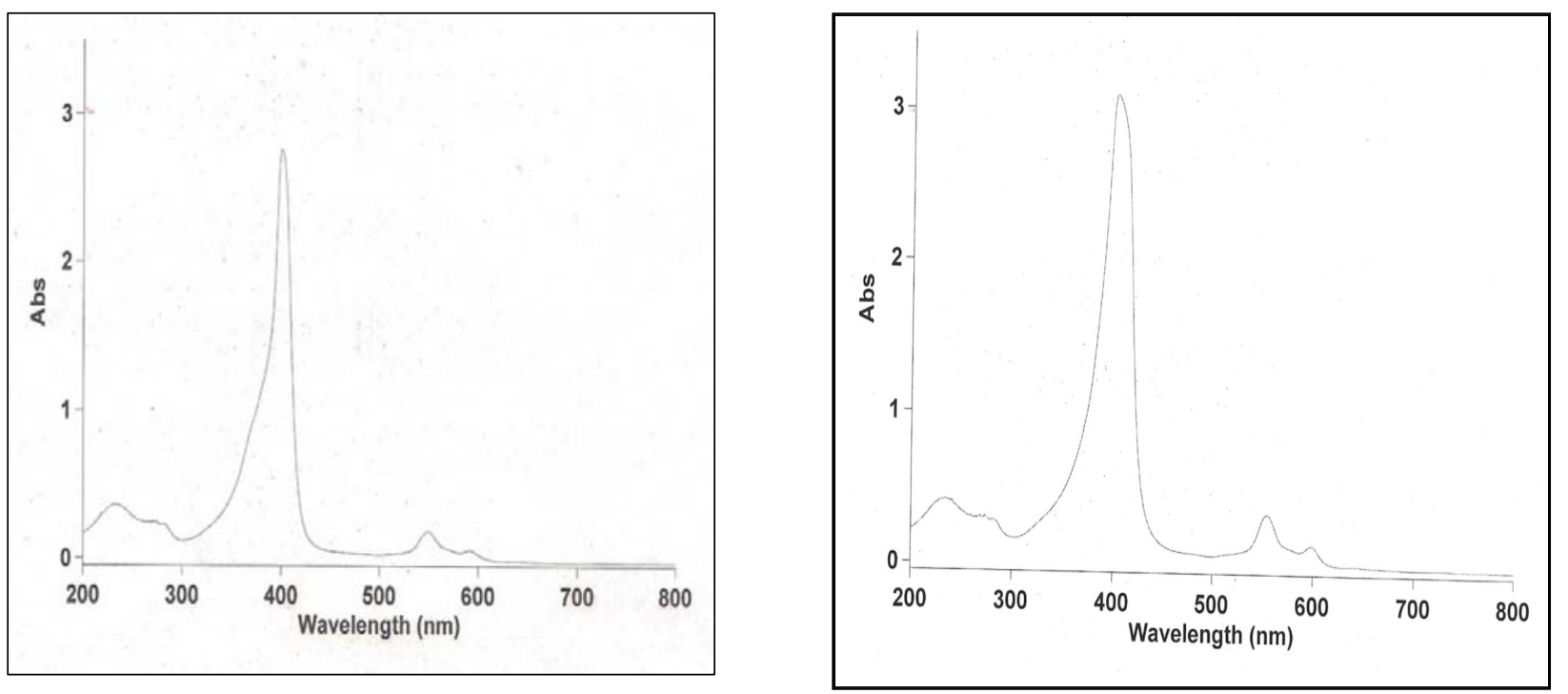

Fig. 3 :Absorption spectra (A) Absorption spectrum of
HpD dissolved in PBS.
(B) Absorption spectrum of $\mathrm{HpD}$ dissolved in ethanol.

Table 2: Peaks of HpD absorption

(A) Peaks of absorption spectrum of $\mathrm{HpD}$ dissolved in PBS.

\begin{tabular}{|l|l|l|}
\hline $\begin{array}{c}\text { Wave lenght } \\
(\mathrm{nm})\end{array}$ & Absorbance & Type of band \\
\hline $\mathbf{5 9 1 . 0 0}$ & $\mathbf{0 . 0 5 9}$ & Q-band \\
\hline $\mathbf{5 5 0 . 0 0}$ & $\mathbf{0 . 1 8 5}$ & Q-band \\
\hline $\mathbf{4 0 0 . 0 0}$ & $\mathbf{2 . 7 6 4}$ & Sort band \\
\hline 273.00 & 0.253 & \\
\hline 271.00 & 0.252 & \\
\hline 232.00 & 0.363 & \\
\hline
\end{tabular}

(B) Peaks of absorption spectrum of HpD dissolved in ethanol.

\begin{tabular}{|l|l|l|}
\hline $\begin{array}{c}\text { Wave lenght } \\
(\mathrm{nm})\end{array}$ & Absorbance & Type of band \\
\hline $\mathbf{5 9 8 . 0 0}$ & $\mathbf{0 . 1 4 4}$ & Q-band \\
\hline $\mathbf{5 5 4 . 0 0}$ & $\mathbf{0 . 3 4 5}$ & Q-band \\
\hline $\mathbf{4 0 1 . 0 0}$ & $\mathbf{3 . 1 0 2}$ & Sort band \\
\hline 273.00 & 0.311 & \\
\hline 268.00 & 0.312 & \\
\hline 233.00 & 0.421 & \\
\hline
\end{tabular}




\section{REFERENCES}

Akdeniz, B.G.; Koparal, E.; Sen, B.H.; Ates, M.; Denizci, A.A. (2002). Prevalence of Candida albicans in oral cavities and root canals of children. J. Dent. Child., 69 (3), 289-292.

Al-Khafaji A.S.; Al-Shamery A.M.; Subhi, S. (2010). Photodynamic action of low power He-Ne laser on photosensitized human Hep-2 and AMN3 cell lines with hematoporphyrin derivative in vitro. Iraqi J.Cancer Med. Genet., 3(1), 54-60.

Al-Khafaji, A.S. (2002). A study of the effect of photosensitization technique by low-power He-Ne laser on Pseudomonas earuginosa infecting burn wounds. M.Sc. thesis, University of Baghdad, Baghdad, Iraq, p: 54-57

Athar, M.; Mukhtar, H.; Bickers, D.R. (1988). Differential role of reactive oxygen intermediates in photofrin-I and photofrin-II mediated photoenhancement of lipid peroxidation in epidermal microsomal membranes, J. Invest. Dermatol., 90, 652657.

Baena, M.T.; Moreno, M.M.; Franco, M.F.; Adalpe, B.B.; Quindos, G.; Sanches, V.L. (2005). Candida albicans, Staphylococcus aureus and Streptococcus mutans colonization in patients wearing dental prosthesis. Med. Oral Patol. Oral Cir. Bucal., 10(1), 27-39.

Bertoloni, G.; Zambotto, F.; Conventi, L.; Reddi, E.; Jori, G. (1987). Role of specific cellular targets in the hematoporphyrin-sensitized photoinactivation of microbial cells. Photochem. Photobiol. 46, 695-698.

Bliss, J.M.; Bigelow, C.E.; Foster, T.H.; Haidaris; C.G. (2004). Susceptibility of Candida species to photodynamic effects of photofrin. Antimicrob. Agents Chemother., 48,2000-2006.

Bocking, T.; Barrow, K. D.; Netting, A.G.; Chilcott, T.C.; Coster, H.G.; Hofer, M. (2000). Effects of singlet oxygen on membrane sterols in the yeast Saccharomyces cerevisiae. Eur. J. Biochem., 267, 1607-1618.

Dougherty, T. J.; Gomer, C. J.; Henderson, B. W.; Jori, G.; Kessel, D.; Korbelik, M.; Moan, J.; Peng, Q. (1998). Photodynamic therapy. J. Natl. Cancer Inst., 90, 889-905.

El Azizi, M.A.; Starks, S.E.; Khardori, N. (2004). Interactions of Candida albicans with other Candida spp. and bacteria in the biofilms. J. Appl. Microbiol., 96, 10671073.

Kandela, S.A., Melconian, A.K. and Al-Khafaji, A.S. (2004). Optimum Photosensitization of pathogenic bacteria using low power laser. J. Al-Nahrain Univer., 8(2), 54-62.

Lambrechts, S. A.; Aalders, M.C.; Van Marle, J. (2005). Mechanistic study of the photodynamic inactivation of Candida albicans by cationic porphyrin. Antimicrob. Agents Chemother., 49, 2026-2034.

Malik, Z.; Hanania, J.; Nitzan, Y. (1990). Bactericidal effects of photoactivated porphyrins an alternative approach to antimicrobial drugs. J. Photochem. Photobiol., 5, 281293.

Mang, T. S.; Sullivan, M.; Cooper, M.; Loree, T.; Rigual, N. (2006). The use of photodynamic therapy using $630 \mathrm{~nm}$ laser light and porfimer sodium for the treatment of oral squamous cell carcinoma. Photodiagn. Photodyn. Ther., 3, 272275. 
Merchat, M.; Spikes, J. D.; Bertoloni, G.; Jori, G. (1996). Studies on the mechanism of bacteria photosensitization by meso-substituted cationic porphyrins. $J$. Photochem. Photobiol., 35, 149-157.

Ochsner, M. (1997). Photophysical and photobiological processes in the photodynamic therapy of tumours. J. Photochem. Photobiol., 39, 1-18.

Paardekooper, M.; De Bruijne, A. W.; Steveninck, J. V.; Van den Broek, P. J. (1995). Intracellular damage in yeast cells caused by photodynamic treatment with toluidine blue. Photochem. Photobiol., 61, 84-89.

Redmond R. W.; Gamlin, J. N. (1999) A compilation of singlet oxygen yields from biologically relevant molecules. Photochem. Photobiol., 70, 391-475.

Sen, B.H.; Kamran, E.S.; Larz, S.W. (1997). Growth patterns of Candida albicans in relation to radicular dentin. Oral Surg. Oral Med. Oral Pathol., 84, 68-73.

Souza, S.C.; Junqueira, J.C.; Balducci, I.; Koga-Ito, C.Y.; Munin, E.; Jorge, A.O.C. (2006). Photosensitization of different Candida species by low power laser light. $J$. Photochem. Photobiol.,. 83, 34-38.

Teichert, M.C.; Jones, M.D.; Usacheva, M.N.; Biel, M.A. (2002). Treatment of oral candidiasis with methylene blue-mediated photodynamic therapy in an immunodeficient murine model. Oral Surg. Oral Med. Oral Pathol. Oral Radiol. Endod., 93, 155-160.

Williams, D.W.; Lewis, M.A. (2000). Isolation and identification of Candida from the oral cavity. Oral Dis., 6, 3-11

Wilson, M. (1993). Photolysis of oral bacteria and its potential use in the treatment of caries and periodontal disease: a review. J. Appl. Bacteriol., 75:299-306.

Wilson, M.; Dobson J.; Harvey, W. (1992). Sensitization of oral bacteria to killing by lowpower laser radiation. Curr. Microbiol., 25, 77-81.

Wohlfarth, C. (1995). "Chemistry and Physics" Lide and Frederikse, Inc., Boca Raton, Florida, pp. 159-209. 